\title{
Feeding Management of Red Jungle Fowl Offsprings by Community in Seluma District, Bengkulu, Indonesia
}

\author{
Sutriyono $^{1 *}$, J. Setianto ${ }^{1,2}$ and A. H. K. Amrullah ${ }^{1}$ \\ ${ }^{1}$ Department of Animal Husbandry, Faculty of Agriculture, University of Bengkulu, Jl. W.R. Supratman Kandang Limun, \\ Bengkulu 38371, Indonesia. Tel./Fax. + 62-736-21290 \\ ${ }^{2}$ Postgraduate Program in Natural Resources and Environmental Management, Faculty of Agriculture, University of Bengkulu. \\ Jl. W.R. Supratman Kandang Limun, Bengkulu 38371. Tel./Fax. + 62-736-21290 \\ *Corresponding author. Email : itrusaryono@gmail.com
}

\begin{abstract}
Domestication of red jungle fowl has been done in Seluma District, Bengkulu Indonesia. Domestication is done for many purposes, and has produced breeds of burgo chicken, which is currently bred. The objective of the study was to evaluate the feeding management vof red jungle fowl and its offspring by the community. The study was conducted in Seluma District of Bengkulu Indonesia. Respondents selection was conducted by using a snowball sampling method, obtained 45 samples of breeders. The data were obtained from the breeders selected as respondents by using a combination of in-depth interviews, questionnaires and a direct observation. The results showed that the respondents gave the feed of one type, two types, three types, four types and five types of feed, respectively $42.22 \%, 35.56 \%$, $15.56 \%, 4.44 \%$, and $2.22 \%$. Respondents provide feed with frequency one time per day, twice per day, and three times per day respectively $28.89 \%, 51.11 \%$, and $20 \%$. Respondents provide feed in the morning of $20 \%, 8.89 \%$ noon, morning and afternoon $51.11 \%$, and morning, noon and afternoon $20 \%$. Respondents who feed $40 \%$ of corn, $48.89 \%$ of rice, $40 \%$ commercial feed, $13.33 \%$ rice, $2.22 \%$ red rice, $15.56 \%$ rice, $8.89 \%$ rice bran, $15.56 \%$ palm fruit, $4.44 \%$ ant eggs. It can be concluded that feed management is varied and has not considered nutritional needs for growth, production and reproduction.
\end{abstract}

Keywords: red jungle fowl offsprings, feed, management

\section{INTRODUCTION}

Red jungle fowl (Gallus gallus) is a wildlife that lives in various regions of Indonesia. Bengkulu Province is one of the living and breeding places of red jungle fowl. Forests, crops, and agricultural cultivation areas are so wide that they support red jungle fowl to live and reproduce. Red jungle fowl liked the surrounding areas of cultivation and residential areas, living perched on tree branches with a height of approximately 5 meters above the ground, living in groups of 4-8 individuals, and living from the lowlands up to a plateau with a height of 2500 meters [1]. The destruction of habitat, the presence of predators, and poaching threaten the existence of red jungle fowl leading to extinction [2]. Until now, people in Bengkulu are still hunting red jungle fowl in nature [3]. Formal conservation has not been done by government and private institutions. Nevertheless, some societies have domesticated red jungle fowl as a form of conservation [4]. In animal domestication the limiting factor is reduced, provided feed and shelter, protected from unfavorable climatic disturbances, and protection from predators. In contrast, domesticated animals often live in limited space and animals must tolerate high density with their relatives [5]. Animal welfare will decrease if resources become limited, resulting in a negative response to production performance [6,7]. Humans change animal behavior and do selection on domesticated animals. The domestication process produces fundamental changes in behavior, physiology, and production, but there are still some similarities between ancestors and the domesticated [8]. It is further explained that in domestication there are rapid genetic changes such as growth, production, and reproduction.
Domestication of red jungle fowl in Bengkulu has produced a new species called burgo chicken, which is a cross between male red jungle fowl and female village chicken [4] Burgo chicken is one type of endemic poultry in Bengkulu, with the name is Rejang chicken, Bath chicken, and Ratus chicken [9[. Burgo chicken has several advantages that are more resistant to disease, egg production is high, and rooster has a distinctive voice, and the color of the feather is beautiful, so it can be used as an ornamental animal [10]. The community are rearing burgo chicken for the purpose of meat production, egg production, ornamental chicken, hunting chicken, and chicks production. The burgo chicken that is reared by the community comes from purchasing, crossing red jungle fowl with village chicken, and comes from the giving of his brother [11]. The weight of burgo chicken can reach 1.25 kilograms, and egg production is 6.89 eggs per hen per period, and chick production reaches 56 chicks per hen per year [12]. The rearing of burgo chicken by the community in North Bengkulu is kept in cages during the day and night, kept in cages at night and released during the day, released during the day and night, and kept on perch [3]. The condition of population of red jungle fowl and burgo chicken in 2016 is still very low when compared to other local chickens The population of red jungle fowl and their offspring are 846 , which is reared by 167 breeder [11]. The cause of the slow growth of the burgo chicken population is unknown.

Feed and environmental factors affect the performance of poultry [13] [14]. Protein and energy content of feed affect various growth parameters, such as weight gain, feed conversion and growth rate in chickens [15]. Therefore, improving the nutrient content of feed such as crude protein and energy can 
improve the growth performance of chicken. Nevertheless, the choice to improve the feeding of local chicken by breeder in limited economic conditions is difficult to adopt [16]. This study aims to evaluate the feeding management of red jungle fowl and its offspring in Seluma District, Bengkulu, Indonesia.

\section{MATERIALS AND METHODS}

The study was conducted in Seluma district, Bengkulu province, Indonesia. The selection of the study sites was determined purposively with the consideration that in that area the community has domesticated red jungle fowl. The sample of breeder is determined by snowball sampling method. Sampling is done by finding a red jungle fowl breeder and its offspring, then do the data collection. The other sample of breeder is then searched based on the first sample information. All samples of farmers are recorded, then coordinated to get the agreement of data retrieval time. The number of respondents selected is 45 farmers, then conducted in-depth interviews. The main data collected through interviews, filling questionnaires, and direct observation, while supporting data obtained through related libraries. Data collected include the number of feed types, feeding frequency, feeding time, and type of feed. The data obtained are presented in the form of tables and drawings and analyzed descriptively.

\section{RESULTS AND DISCUSSION}

\subsection{General Condition of Research Sites}

Seluma District, Bngkulu Province, Indonesia is located on the West Coast of Southern Sumatra and is located at $03^{\circ} 49^{\prime} 55.66^{\prime \prime S L}-04^{\circ} 21^{\prime} 40,22^{\prime \prime S L}$ and $101^{\circ} 17^{\prime} 27.57^{\prime \prime E B}-$ $102^{\circ} 59^{\prime} 40,54^{\prime \prime E B ~[17] . ~ T h e ~ a r e a ~ o f ~ S e l u m a ~ d i s t r i c t ~ i s ~} 4,128.44$ $\mathrm{km}^{2}$, consisting of $2,400.44 \mathrm{~km}^{2}$ of land, consisting of $1,728 \mathrm{~km}^{2}$ of sea and $76.4 \mathrm{~km}^{2}$ of coastline. Seluma district consists of 14 sub-districts; 182 villages and 20 urban villages. The population in 2014 is 183,420 people, consisting of 94,186 male and 89,234 female [17]. The number of workers in 2014 is 91,389 people, and 59,028 people or $67 \%$ work in the agricultural sector. Population density reached 74 people per $\mathrm{km}^{2}$ [17]. The condition makes it possible to develop red jungle fowl and their offspring

\subsection{Feeding Management}

Based on observations and interviews with breeders, chickens obtain feed in two ways: from giving by breeders and getting feed from nature. Chickens are kept in cages at night and released during the day get feed from breeders and from nature. While chickens are kept on perch and chickens are kept in cages during the day and night get the feed from the breeder. The management of the burgo chicken feed includes feed ingredients used, the number of feed types (feed diversity), the frequency of feeding, and feeding time is different among breeders (Table 1 , Table 2, Table 3, Table 4).

\subsection{Feed ingredients}

Feed ingredients given by breeders to red jungle fowl and its offspring (burgo chicken) are nine types that include corn ( $40 \%$ breeders), grain $(48.89 \%$ breeders), commercial feed ( $40 \%$ breeders), rice ( $13.33 \%$ breeders), brown rice ( $2.22 \%$ breeders), cooked rice (15.56\%), Bran (8.89\% breeder), fruit palm (15.56\% breeders), ant egg (4.44\% breeders) (Table 1$)$.

\section{Table 1. Feed ingredients of red jungle fowl and its offspring in Seluma District, Bengkulu, Indonesia}

\begin{tabular}{|l|c|c|l|}
\hline \multirow{2}{*}{$\begin{array}{c}\text { Feed } \\
\text { ingredients }\end{array}$} & \multicolumn{2}{|c|}{ Amount of } & \multicolumn{1}{|c|}{ Description } \\
\cline { 2 - 3 } 1. Corn & breeder & $\%$ & $\begin{array}{l}\text { Feed is given to } \\
\text { chicks, hens, and } \\
\text { rooster }\end{array}$ \\
\hline 2. Rice grain & 22 & 48.89 & $\begin{array}{l}\text { Feed is given to } \\
\text { hens and rooster }\end{array}$ \\
\hline $\begin{array}{l}\text { 3. Feed } \\
\text { Commercial }\end{array}$ & 18 & 40.00 & $\begin{array}{l}\text { Feed is given to } \\
\text { chicks }\end{array}$ \\
\hline 4. Rice & 6 & 13.33 & $\begin{array}{l}\text { Feed is given to } \\
\text { hens and rooster }\end{array}$ \\
\hline 5. Brown Rice & 1 & 2.22 & $\begin{array}{l}\text { Feed is given to } \\
\text { chicks, }\end{array}$ \\
\hline $\begin{array}{l}\text { 6. Cooked } \\
\text { Rice }\end{array}$ & 7 & 15.56 & $\begin{array}{l}\text { Feed is given to } \\
\text { hens and rooster }\end{array}$ \\
\hline 7. Bran & 4 & 8.89 & $\begin{array}{l}\text { Feed is given to } \\
\text { hens and rooster }\end{array}$ \\
\hline $\begin{array}{l}\text { 8. Fruit palm } \\
\text { 9. Ant egg } \\
\text { (kroto) }\end{array}$ & 7 & 15.56 & $\begin{array}{l}\text { Feed is given to } \\
\text { hens and rooster }\end{array}$ \\
\hline
\end{tabular}

The amount of feed ingredients used by farmers quite a lot, but when compared with his ancestors (red jungle fowl) that live in nature then the number is less. Red jungle fowl consumed 26 invertebrate orders and 12 plant species. Feed consumption from plant is $80,88 \%$ and feed consumption from animal is $19,12 \%$ [18]. Poultry has the ability to choose feed ingredients according to their nutritional needs. The low available feed material causes the choice of feed by the poultry to be reduced, resulting in the lack of nutrients needed. Food is the source of nutrients and energy. The energy in food serves as a fuel for the metabolic processes of animals. In this study, breeder give feed to the chicken is not based on the nutrients needed by the chicken, but depend on the available feed and rearing methods of chicken. Chickens kept in cages during the day and night are given grain feed (grain, corn, rice, brown rice), commercial feed, and feed ingredients from animals. Chickens are kept in cages at night and released during the day are given feed in the form of grain (rice and corn) and cooked rice. While chickens that are kept on perch are given feed in the form of grain, corn, and commercial feed. Breeders give feed to the chickens by not mixing feed ingredients into a ration like commercial rations, but feed ingredients are given separately with different feeding times. Feeding the bird separately is not beneficial. Bird can choose the feed according to its nutritional needs. Each bird can accurately select its balance of nutrient to meet its particular physiological requirement [19]. As long as the hens are given the opportunity to make clear, easy nutritional choices, they will be healthy and productive. They can indulge their natural appetites, can develop a normal digestive tract and a degree of natural resistance to coccidiosis. Changes in requirements, as birds grow, are also met by appropriate changes in selection [19]. 


\subsection{Amount of feed ingredients}

The variety of feed ingredients given by the breeders to chickens varies from one type to five types. The breeders provide one type of feed is $42.22 \%$, the two feed types are $35.56 \%$, the three feed types are $15.56 \%$, the four feed types are $4.44 \%$, and the five feed types are $2.22 \%$ (Table 2 ).

Table 2. The number of feed types for the red jungle and its offspring provided by the breeder in Seluma District, Bengkulu, Indonesia

\begin{tabular}{|c|c|c|c|}
\hline \multirow{2}{*}{ Type of feed } & \multicolumn{2}{|c|}{ Amount of } & \multirow{2}{*}{ Description } \\
\hline & breeder & $\%$ & \\
\hline $\begin{array}{c}1 \text { type of } \\
\text { feed }\end{array}$ & 19 & 42.22 & $\begin{array}{l}\text { Feed is given to } \\
\text { chicks, chickens } \\
\text { released during the } \\
\text { day and night, and } \\
\text { chickens are } \\
\text { released during the } \\
\text { day and kept in } \\
\text { cages at night }\end{array}$ \\
\hline $\begin{array}{c}2 \text { types of } \\
\text { feed }\end{array}$ & 16 & 35.56 & $\begin{array}{l}\text { Feed is given to } \\
\text { chicks, chickens in } \\
\text { cages and perch, } \\
\text { chicken released at } \\
\text { the day }\end{array}$ \\
\hline $\begin{array}{c}3 \text { types of } \\
\text { feed }\end{array}$ & 7 & 15.56 & $\begin{array}{l}\text { Feed is given to } \\
\text { chicks, chickens in } \\
\text { cages and perch, } \\
\text { chicken released at } \\
\text { the day }\end{array}$ \\
\hline $\begin{array}{c}4 \text { types of } \\
\text { feed }\end{array}$ & 2 & 4.44 & $\begin{array}{l}\text { Feed is given to } \\
\text { chicks, chickens in } \\
\text { cages. }\end{array}$ \\
\hline $\begin{array}{c}\text { e. } 5 \text { types of } \\
\text { feed }\end{array}$ & 1 & 2.22 & $\begin{array}{l}\text { Feed is given to } \\
\text { chickens in cages, }\end{array}$ \\
\hline
\end{tabular}

Feed ingredients derived from plants and animals. Feed ingredients from plants are given in chickens by all breeders, while animal feed is given to chicken only $4.44 \%$. Feed ingredients are given to chickens separately and not mixed into one material such as commercial feed. Giving is done intermittently depending on available feed ingredients. Therefore, the feed given by the breeders in general is not sufficient for the nutritional needs of chickens, especially in chickens kept in cages during the day and night and chickens are kept on perch. Chickens are kept in the cage at night and released during the day get feed from breeders and feed from nature, so the nutritional needs and the amount of feed is more fulfilled. Thus, chickens that are kept in cages at night and released during the day can choose to feed according to taste and according to the needs of the chicken for growth, production and reproduction. In nature, Red jungle fowl eats a wide variety of animals and plants. Foods derived from plants include palm fruit, Chiku (Achras sapota), papaya (Carica papaya), Cempedak (Artocarpus integer), rubber (Hevea brasiliensis), nuts, and seeds Macaranga sp. Other types of feed are snails, eggshells, bones. Red jungle fowl males consume more palm fruit than in females, and females consume more invertebrates and vertebrates than males (18 Arshad et al., 2000). However, the burgo chicken released during the day causes the chicken to escape and then fleeing into the forest and the plantation as a feral animal. This still occurs in the offspring of red jungle fowl (F1, F2 and F3) that still exhibit wild properties. Meanwhile, animal feed is Dermaptera, Hymenoptera, Isoptera, Orthoptera, Coleoptera, Crustacea (Isopoda), leeches and snails are the main food

\subsection{Feeding frequency}

The frequency of feeding by breeders varies from once per day to three times per day. Farmers provide feed with frequent one time per day is $28.89 \%$ breeders, twice per day is $51.11 \%$ breeders, and three times per day is $20 \%$ breeders (Table $3)$.

\section{Table 3. Frequency of feeding on red jungle fowl and its offspring in Seluma District, Bengkulu, Indonesia}

\begin{tabular}{|l|c|c|l|}
\hline \multirow{2}{*}{$\begin{array}{c}\text { Feeding } \\
\text { frequency }\end{array}$} & \multicolumn{2}{|c|}{ Amount of } & \multirow{2}{*}{ Description } \\
\cline { 2 - 4 } a. 1 time per & breeder & $\%$ & $\begin{array}{l}\text { Feed is given to } \\
\text { chicken released } \\
\text { at the day and } \\
\text { night, chickens } \\
\text { are released at the } \\
\text { day and kept in } \\
\text { cages at night }\end{array}$ \\
\hline b. 2 times per \\
day
\end{tabular}

Frequency of feeding once per day is given to chickens that are kept by way of release during the day, and feeding three times per day is given to chicks kept in cages during the day and night. While the frequency of feeding twice per day given to chicks, and adult chickens are kept in cages and kept on perch. Some of the advantages of frequent feeding frequencies are chicken sufficiency feed requirements, can control chicken health and chicken safety, and control over environmental conditions. If the requirement of feed is fulfilled and the environmental conditions are suitable for the chicken then the performance of growth, production and reproduction will be better. The problem faced in the feeding is the lack of manpower in raising the chicken burgo. Breeder of burgo chicken has a livelihood as a farmer, therefore farmers are more concerned with the main job. This causes the chicken to lack feed, which resulted in the chicken lack of nutrients. Nutrition has an effect on reproduction performance. The $16 \%$ dietary protein is the optimal level for male red jungle fowl to maintain its reproductive performance [20]. These results were in general 
agreement with those reported by [21] and [22] as confirmed that increasing feeding frequency to 2 times per day affects the productive performance of broiler breeder hens. Feeding broiler breeder hens 2 or 3 meals per day improved the reproductive performance during the early lay cycle. Implementing twice or thrice a day feeding regimens altered hepatic lipogenic gene expression in broiler breeder hens only at peak egg production, which indicated a short-term effect of increasing feeding frequency on hepatic lipid metabolism [23]. Local chickens reared under intensive feeding system have better growth performance and survival rate compared to those under semiscavenging when reared on-farm. Local chickens fed $18 \% \mathrm{CP}$ : $2800 \mathrm{Kcal} \mathrm{ME} / \mathrm{kg}, 20 \% \mathrm{CP}: 2900 \mathrm{Kcal} \mathrm{ME} / \mathrm{kg}$ and $23 \% \mathrm{CP}$ : $3200 \mathrm{Kcal} \mathrm{ME} / \mathrm{kg}$ diets gave similar response in terms of growth during 0-6 week growing period. Therefore, a diet containing $18 \% \mathrm{CP}: 2800 \mathrm{kcal} \mathrm{ME} / \mathrm{kg}$ is sufficient for rearing local chickens in the early growth phase [24]. In this study, more than $50 \%$ of breeders provide feed twice a day, with a limited number of feedstocks in the form of whole grains. For chickens released during the day will be able to obtain additional food from nature, but for chickens kept in cages during the day and night and chickens that are kept on perch can not choose the feed. The addition of feed with sufficient quantity and good quality will increase the cost for the farmers, therefore it is difficult to be adopted by breeders. Changing the way red jungle fowl maintenance by releasing chickens during the day, can help in sufficient feed needs in chickens. The problem is red jungle fowl and their offspring are still wild, so if released during the day then the chicken will run into the forest as a feral animal and prefer to sleep on the branches of trees. Therefore, changing the nature of red jungle fowl and its offspring from wild to benign is a very good way to rearing of red jungle fowl.

\subsection{Feeding time}

Breeders giving of feed to the red jungle fowl and their offspring are done in the morning, midday and afternoon (Table 4). Breeders feed in the morning is $20 \%$ of the total breeders, at midday is $8.89 \%$ of the total breeders, in the morning and afternoon is $51.11 \%$ of the total breeder, morning and midday and afternoon is $20 \%$ of the total ranchers (Table 4 ).

The influence of feeding time on the performance of red jungle fowl and its offspring has not been studied, but in other poultry especially broiler has been much studied. Feeding time affects egg production, egg quality, reproductive efficiency and oviposition time [25]. [26] reported that the best performance in terms of egg production, fertility and hatchability in broilers was achieved by feeding chickens twice per day with $75 \%$ feed at 16.00 and $25 \%$ feed at 12.00 . [27] reported that egg production was higher in hens fed at midday than in the morning feed. Further explained that the chickens eat more feed at midday, so egg production is high. While the quality of eggs related to the nutrient content, especially Calcium $(\mathrm{Ca})$ for the formation of egg shells. Normal egg shell formation begins in the afternoon or evening so the use of feeding $\mathrm{Ca}$ in the morning is bad, which is caused by the inability of poultry in utilizing $\mathrm{Ca}$ [28]. While feeding more on lunch will increase egg weight [29]. Poultry feeding times also affect the reproductive efficiency. This is related to sperm and spermatoxoa production, which results in the highest in the afternoon [28]. Therefore, feeding on red jungle fowl and its offspring need to calculate the time of administration, so that the nutrients obtained by the chicken can be utilized to obtain higher productivity and better reproduction process and efficient.
Table 4. Time feeding on the red jungle fowl and its offspring in Seluma District, Bengkulu, Indonesia

\begin{tabular}{|c|c|c|c|}
\hline \multirow{2}{*}{ Feeding time } & \multicolumn{2}{|c|}{ Amount of } & \multirow{2}{*}{ Description } \\
\hline & breeder & $\%$ & \\
\hline $\begin{array}{l}\text { a. Feed is } \\
\text { given in the } \\
\text { morning }\end{array}$ & 9 & 20.00 & $\begin{array}{l}\text { Feed is given to } \\
\text { chicks. chickens in } \\
\text { cages, chickens } \\
\text { released at the day, } \\
\text { chicken on perch }\end{array}$ \\
\hline $\begin{array}{l}\text { b. Feed is } \\
\text { given at } \\
\text { noon }\end{array}$ & 4 & 8.89 & $\begin{array}{l}\text { Feed is given to } \\
\text { chickens released } \\
\text { at the day and night }\end{array}$ \\
\hline $\begin{array}{l}\text { c. Feed is } \\
\text { given in the } \\
\text { morning } \\
\text { and } \\
\text { afternoon }\end{array}$ & 23 & 51.11 & $\begin{array}{l}\text { Feed is given to } \\
\text { chickens released } \\
\text { at the day, chicken } \\
\text { in cage, chicken on } \\
\text { perch }\end{array}$ \\
\hline $\begin{array}{l}\text { d. Feed is } \\
\text { given in the } \\
\text { morning, } \\
\text { noon, } \\
\text { afternoon }\end{array}$ & 9 & 20.00 & $\begin{array}{l}\text { Feed is given to } \\
\text { chicks, chickens in } \\
\text { cages, chickens } \\
\text { released at the day, } \\
\text { chicken on perch }\end{array}$ \\
\hline
\end{tabular}

\subsection{Drinking Water}

Based on observations at the study sites, the farmers who provide drinking water are $86.67 \%$ of the total breeders and and do not provide drinking water is $13.33 \%$ of the total breeders. Of the breeders providing drinking water, $94.87 \%$ provided ad libitum drinking water and $5.13 \%$ of farmers provided limited drinking water (Table 5). Indicator of water with limited is the existence of emptiness of drinking water at certain times. Drinking water is provided by breeders in chickens kept in cages during the day and night, chickens kept on perch, chickens kept in cages, and chickens kept in cages at night and released during the day. Conversely, chickens released during the day and night are not provided with drinking water.

\section{Table 5. Drinking water supply to red jungle fowl in Seluma District, Bengkulu, Indonesia}

\begin{tabular}{|c|c|c|c|}
\hline \multirow{2}{*}{$\begin{array}{c}\text { Drinking } \\
\text { water }\end{array}$} & \multicolumn{2}{|c|}{ Amount of } & \multirow{2}{*}{ Description } \\
\hline & breeder & $\%$ & \\
\hline $\begin{array}{ll}\text { a. } & \text { Water } \\
\text { provided by } \\
\text { breeders }\end{array}$ & 39 & 86.67 & $\begin{array}{l}\text { Chicks, chickens } \\
\text { kept in cages } \\
\text { during the day and } \\
\text { night, chickens } \\
\text { released during the } \\
\text { day and kept in } \\
\text { cages at night, } \\
\text { chickens kept on } \\
\text { perch }\end{array}$ \\
\hline $\begin{array}{l}\text { b. Water not } \\
\text { provided by } \\
\text { breeders }\end{array}$ & 6 & 13.33 & $\begin{array}{l}\text { Chicken is released } \\
\text { during the day and } \\
\text { at night }\end{array}$ \\
\hline
\end{tabular}




\begin{tabular}{|c|c|c|c|}
\hline $\begin{array}{l}\text { c. Provision } \\
\text { of drinking } \\
\text { water in } a d \\
\text { libitum }\end{array}$ & 37 & 94.87 & $\begin{array}{l}\text { Drinking water is } \\
\text { given to chickens } \\
\text { kept in cages } \\
\text { during the day and } \\
\text { night, chickens are } \\
\text { released during the } \\
\text { day and kept in } \\
\text { cages at night, } \\
\text { chickens kept on } \\
\text { perch }\end{array}$ \\
\hline $\begin{array}{l}\text { d. } \text { The } \\
\text { provision } \\
\text { of drinking } \\
\text { water is } \\
\text { limited }\end{array}$ & 2 & 5.13 & $\begin{array}{l}\text { Drinking water is } \\
\text { given to chickens } \\
\text { released during the } \\
\text { day and kept in } \\
\text { cages at night, }\end{array}$ \\
\hline
\end{tabular}

\section{CONCLUSION}

Red jungle fowl and its offspring is a type of poultry raised some people in Seluma District, Bengkulu, Indonesia. Feeding in poultry is distinguished by age and method of raising chickens. Chicks are fed with a frequency of two to three times per day; and feed ingredients given are milled corn, commercial feed, and ant eggs; and chicken feed is put in place of feed. Male and female chickens are fed milled corn, bran, rice paddy, rice seeds, cooked rice, palm fruit, and commercial feed; feed given one to three times per day; by being put in a feeding place and sown on the floor. Chickens that are released during the day and kept in cages at night are fed between one to two times per day, and feed is given in the morning or in the morning and afternoon. Chickens that are released during the day and night are fed with a frequency of one time per day, and feed is given between the morning until midday. Chickens kept on perch and kept in cages during the day and night are fed between two to three times per day, and feed is given in the morning and evening or in the morning and at noon and in the afternoon. Drinking water is provided for chickens kept in cages at night and released during the day, chickens kept on perch, chickens kept in cages, and chicks. Chickens released during the day and night are not provided with drinking water. Feeding on red jungle fowl by breeders is not based on nutritional needs for growth and production, but based on how to raise chickens.

\section{REFERENCES}

[1] F. Akrim, T. Mahmood, M.S. Awan, S.Q. Butt, D.E. Shawar, M.A. Asadi and I. Zangi, 'Habitat preference and roosting behaviour of the Red Junglefowl Gallus gallus (Aves: Galliformes: Phasianidae) in Deva Vatala National Park, Azad Jammu \& Kashmir, Pakistan', Journal of Threatened Taxa, vol. 8, no. 9, pp. 9138-9143, 2016, doi: http://dx.doi.org/10.11609/jott.2256.8.9.9138-9143.

[2] J. Setianto, B. Zain; Sutriyono; H. Prakoso, 'Domestication of red jungle fowl: A case study of the red jungle fowl chicks procurement by the communities in Central Bengkulu, Indonesia', Biodiversitas Vol.18, no. 1, pp.183-189, 2017, doi: 10.13057/biodiv/d180125.

[3] J. Setianto, H. Prakoso; Sutriyono, ''Domestication of red jungle fowl: A case study of red jungle fowl poaching by communities in North Bengkulu', Pros. Sem. Nas. Masy.
Biodiv. Indon., vol. 1, no. 2, pp. 207-212. 2015, doi: $10.13057 / \mathrm{psnmbi} / \mathrm{m} 010207$.

[4] J. Setianto, H. Prakoso dan Sutriyono, 'Dynamics of Burgo Chicken Population and Development Strategy in Bengkulu', Faculty of Agriculture, University of Bengkulu, Indonesia, 2013.

[5] E.O. Price, 'Behavioral development in animals undergoing domestication', Applied Animal Behaviour Science, vol. 65, pp. 245-271, 1999, doi: 10.1016/S01681591(99)00087-8.

[6] R.G. Beilharz, and G. Nitter, "The missing E: the role of the environment in evolution and animal breeding", Journal of Animal Breeding and Genetics vol. 115, pp. 439-453, 1998, doi: https://doi.org/10.1111/j.14390388.1998.tb00366.x.

[7] K. E SchuE tz \& P. Jensen, "'Effects of resource allocation on behavioural strategies: a comparison of red junglefowl (Gallus gallus) and two domesticated breeds of poultry", Ethology, vol. 107, pp. 753-765, 2001.

[8] Al-nasser, H. Al-khalaifa, A. Al-saffar, F. Khalil, M. Al bahouh, G. Ragheb, A. Al-haddad and M. Mashaly, "Overview of chicken taxonomy and domestication", World's Poultry Science Journal, vol. 63, pp. 295-300, 2007, doi: 10.1017/S004393390700147X.

[9]. J. Setianto, 'Ayam Burgo, Ayam Buras Bengkulu', IPB Press, Bogor, Indonesia, 2009.

[10] Sutriyono, J.Setianto, H.Prakoso, B. Zein, “'Conservation and Utilization of Red Jungle Fowl in the Coastal Areas of North Bengkulu', ISECOASTAL Int. Sem. Proc., Faculty of Agriculture, University of Bengkulu, Bengkulu, Indonesia, pp. 370-376, 2017.

[11] J. Setianto, Sutriyono, H. Prakoso and B. Zain, "Identification of the Origin of the Red Jungle Fowl Reared by Community in Seluma District', J. Sain Peternakan Indonesia, vol. 11, no. 2, pp. 141-152, 2016.

[12] Sutriyono, J.Setianto, H. Prakoso, 'Production and population of the red jungle fowl domestication in North Bengkulu District and population development scenario", Pros. Sem. Nas. Masy. Biodiv. Indon., Bogor, vol. 2, no. 8, pp. 226-231, 2016, doi: 10.13057/psnmbi/m020218.

[13] D. Tadelle. and K. J. Peters, "Indigenous chicken ecotype in Ethiopia: growth and feed utilization potentials", International Journal of Poultry Science, vol. 2, no. 2, pp. 144-152, 2003.

[14] I.A. Yousif and N. M. Eltayeb, 'Performance of Sudanese native Dwarf and Bare Neck chicken raised under improved traditional production system", Agric. Biol. J. N. Am., vol. 2, no. 5, pp. 860-866, 2011.

[15] H.M. Kuietche, J.R. Kana, H.F. Defang, C.D. Tadondjou, D.D.M. Yemdjie and A.Teguia, "Effect of dietary energy level on growth performance and morphometric parameters of local barred chickens at the starter phase", 
Int. J. Biol.Chem. Sci., vol. 8, no. 3, pp. 882-890, 2014. http://ajol.info/index.php/ijbcs.

[16] T.N. Gondwe and C.B.A. Wollny, 'Evaluation of the Growth Potential of Local Chickens in Malawi', International Journal of Poultry Science, vol. 4, no. 2, pp. 64-70, 2005.

[17] Statistics of Seluma Regency 'Seluma Regency in Figures', Central Bureau of Statistics of Seluma Regency Pub., Bengkulu, Indonesia, 2014.

[18] M.I. Arshad., M. Zakarian, A.S. Sajap, A. Ismail, "Food and Feeding Habits of Red Junglefowl', Pakistan Journal of Biological Sciences, vol. 3, no.6, pp. 1024-1026, 2000.

[19] S. Pousga , H. Boly and B. Ogle, 'Choice feeding of poultry: a review', Livestock Research for Rural Developmen,vol. 17, Art. \#45. 2005. Retrieved July 17, 2017. http://www.lrrd.org/lrrd17/4/pous17045.htm.

[20] Fazhana and Azhar, 'Dietary protein and fertility of caged red jungle fowl (Gallus gallus) Male', World Appl. Sci. J. 30 (Innovation Challenges in Multidiciplinary Research \& Practice), pp. 100-102, 2014. doi: 10.5829/idosi.wasj.2014.30.icmrp.15.

[21] J. M. Spradley, M. E. Freeman, J. L. Wilson, and A. J. Davis, 'The influence of twice-a-day feeding on regimens after photostimulation on the reproductive performance of broiler breeder hens", Poult. Sci., vol. 87, pp. 561-568, 2008.

[22] R. Taherkhani, M. Zaghari, M. Shivazad, and A. Zare Shahne, "A twice-a-day feeding regimen optimizes performance in broiler breeder hens", Poult. Sci. vol. 89, pp. 1692-1702, 2010
[23] S. Moradi, M. Zaghari , M. Shivazad , R. Osfoori , and M. Mardi, 'The effect of increasing feeding frequency on performance, plasma hormones and metabolites, and hepatic lipid metabolism of broiler breeder hens', Poult. Sci. vol. 92, pp.1227-1237, 2013

[24] C. Nakkazi, D. R. Kugonza, A. Kayitesi, H. E. Mulindwa and M. W. Okot, 'The effect of diet and feeding system on the on-farm performance of local chickens during the early growth phase', Livestock Research for Rural Development, vol. 27,no. 10, Article \#204. Retrieved April 21, 2021 http://www.lrrd.org/lrrd27/10/nakka27204.html.

[25] M.A. Modu, A.A. Benisheikh, T.A. Jibrin, A.M. Marte \& A.M. Ali, "The Effects of Feeding Time and Regimen on the Performance of Broiler Breeders: A review", Global Journal of Science Frontier Research: D Agriculture and Veterinary, Vol.14 Issue 9, Version 1.0, 2014.

[26] M. G. Soltanmoradi, A. Seidavi, M. Dadashbeiki, Fernando, Delgado, and S. Gamboa, 'Effect of time, amount and frequency of feeding on total egg production, fertility and hatchability in broiler breeders', Archiv Tierzucht 56 vol. 102, pp. 1014 -1022, 2013.

[27] M. Daniel and D. Balnave, ''Responses of crossbred layers fed specific meal times', British Poultry Science, vol. 22, issue 4, pp. 347-354, 1981 https://www.tandfonline.com/doi/abs/10.1080/000716881 $\underline{08447894 .}$

[28] M. Farmer and D.A. Roland, "Influence of dietary ingredients on Calcium utilization in the laying hen, Poult". Sci., vol. 65, pp. 345-351, 1986. 